\title{
Regionalna specjalizacja produkcji rolnej w Polsce \\ Regional specialization of agricultural production in Poland
}

\author{
Anna Kołodziejczak 다 \\ Uniwersytet im. Adama Mickiewicza w Poznaniu \\ Wydział Geografii Społeczno-Ekonomicznej i Gospodarki Przestrzennej \\ ul. Krygowskiego 10, 61-680 Poznań \\ aniaka@amu.edu.pl
}

Zarys treści: Celem artykułu jest przedstawienie zmian w specjalizacji regionalnej produkcji rolnej w Polsce w latach 2004-2019. Poszukiwano odpowiedzi na pytanie, w jakiej produkcji rolnej dany region się specjalizuje i w jakim stopniu. Przyjęto następującą hipotezę badawczą: na zmiany specjalizacji produkcji rolnej w regionach mają wpływ rolnicy korzystający z opłat bezpośrednich oraz innych form pomocy finansowej w ramach Wspólnej Polityki Rolnej. Do określenia poziomu i zmian specjalizacji regionalnej w badaniach wykorzystano iloraz lokalizacji $L Q$ oraz obliczono tempo zmian w trakcie badanego okresu czasu. W badanym okresie produkcja roślinna, która jest bardziej związana z warunkami klimatycznymi niż zwierzęca, charakteryzowała się większym zróżnicowaniem (zmieniała się w czasie). Województwa zachodnie odznaczały się wysokim poziomem specjalizacji produkcji roślinnej. Wynikało to ze struktury agrarnej tych województw, gdzie przeważały gospodarstwa duże i bezinwentarzowe. W przypadku produkcji zwierzęcej sytuacja wyglądała inaczej. Na poziom wskaźnika specjalizacji zwierzęcej produkcji towarowej wpłynął przede wszystkim wyraźny wzrost udziału towarowej produkcji mleka. Dotyczyło to regionów północno-wschodniej Polski tj. podlaskiego i warmińsko-mazurskiego, które również specjalizowały się w produkcji mięsa wołowego.

Słowa kluczowe: specjalizacja produkcji rolnej, produkcja towarowa, iloraz lokalizacji.

\section{Wprowadzenie}

Rolnictwo jest bardzo specyficznym sektorem gospodarki, bowiem poza kapitałem i pracą, występuje również czynnik produkcji, jakim jest ziemia. Jedną z głównych cech wyróżniających produkcję rolną jest jej silne uzależnienie od warunków środowiska przyrodniczego. Na produkcję rolną oprócz warunków środowiskowych istotny wpływ mają czynniki społeczno-ekonomiczne tj. struktura agrarna rolnictwa, organizacja pracy, mechanizacja, rodzaj stosowanych technologii produkcji i związana z nią wydajność czynników produkcji, kultura rolna oraz polityka rolna.

Produkcja rolna ulega ciągłym przemianom ekonomicznym i strukturalnym. Zdaniem Krasowicza (2009) już od lat 90. ubiegłego wieku oddziaływanie czynników ekonomiczno-organizacyjnych na prowadzenie produkcji rolnej jest większe niż warunków przyrodniczych. Ważnym czynnikiem mającym wpływ na produkcję rolną była akcesja Polski do Unii Europejskiej, gdzie rolnictwo zostało objęte Wspólną Polityką Rolną. Poprzez Programy 
Rozwoju Obszarów Wiejskich wspiera się zrównoważoną, konkurencyjną produkcję rolną, prowadzoną w zgodzie z zasadami ochrony gleb i wód, zachowania i poprawiania stanu środowiska przyrodniczego.

Celem opracowania jest przedstawienie zmian regionalnej specjalizacji produkcji roślinnej i zwierzęcej zachodzących w Polsce w latach 2004-2019. Starano się odpowiedzieć na pytanie, w jakiej produkcji rolnej dany region się specjalizuje i w jakim stopniu. Przyjęto następującą hipotezę badawczą: na zmiany specjalizacji produkcji rolnej w regionach mają wpływ rolnicy korzystający z opłat bezpośrednich oraz innych form pomocy finansowej w ramach Wspólnej Polityki Rolnej.

Analizę statystyczną przeprowadzono na podstawie danych dotyczących udziału produkcji towarowej w produkcji globalnej oraz udziału roślinnej i zwierzęcej produkcji towarowej w produkcji towarowej, pochodzących z Banku Danych Lokalnych GUS. Wskaźniki dla poszczególnych województw porównywano do średnich dla Polski jako układu odniesienia. Badania wykonano dla lat 2004. 2007, 2013 i 2019, są to lata początku i końca okresu finansowania działań w ramach Programów Rozwoju Obszarów Wiejskich. Ze względu na brak danych dla 2020 r. wzięto pod uwagę 2019 r.

\section{Podstawy teoretyczne definiowania specjalizacji regionalnej}

Jednym ze sposobów polepszenia efektów działalności produkcji rolnej jest specjalizacja. W badaniach regionalnych nad działalnością gospodarczą bardzo często pojęcie specjalizacji traktuje się jako synonim słowa koncentracja. Nie bierze się pod uwagę istotnych różnic wynikających z charakteru tych procesów, a zwłaszcza ich przestrzennej (aglomeracja) i sektorowej (koncentracja) specyfiki. Badacze wykorzystują te same metody estymacji stanu i zmian procesów bez zwracania uwagi na konsekwencje ich identyfikacji raz w przestrzeni ciągłej (aglomeracja), a innym razem w przestrzeni nieciągłej (koncentracja). Prowadzi to do sytuacji, w której bardzo często tę samą zależność identyfikowaną tymi samymi miernikami opartymi na tych samych zmiennych autorzy określają różnymi pojęciami (Kopaczewska et al. 2016). Przyjmuje się, że aglomeracja regionalnej działalności gospodarczej jest to proces skupiania przestrzennego podmiotów (gospodarstw rolnych) w granicach regionu. Identyfikacja aglomeracji polega na określaniu gęstości sieci tworzonej przez punkty stanowiące miejsce lokalizacji poszczególnych gospodarstw rolnych w granicach regionu, w przestrzeni ciągłej (continuous space). W przypadku koncentracji regionalnej działalności gospodarczej jest to proces skupiania się ekonomicznego podmiotów gospodarczych $w$ regionie $w$ aspekcie sektorowo-produkcyjnym. Nie ma ona związku z lokalizacją podmiotów gospodarczych tylko z ich profilem działalności gospodarczej, której wielkość określa się za pomocą liczby podmiotów, liczby pracowników, wartości dodanej brutto lub wartości eksportu. Ma ona zawsze charakter relatywny i jest rozpatrywana w ujęciu wewnętrznym lub zewnętrznym sektorowym i geograficznym (Kopaczewska et al. 2016).

Identyfikując specjalizację regionalną należy zwracać uwagę na takie przypadki, gdzie będzie ona występować nawet przy niskim poziomie aglomeracji i koncentracji działalności gospodarczej (Camagni et al. 2016). Tym samym aglomerację i koncentrację regionalnej działalności gospodarczej rozumiemy jako wymiary wykorzystywane w identyfikacji procesu specjalizacji regionalnej, a nie jej stricte składowe. W badaniach Overman et al. 
(2009) wskazywali, że relatywnie najmniejsze korzyści aglomeracji przy ponadprzeciętnej koncentracji sektorowej osiągają rolnictwo i rybołówstwo. Tak rozumiana specjalizacja regionalna wynika z unikatowości miejsca (regionu), a nie specyfiki aglomeracyjnej. Łącznie występująca unikatowość i koncentracja sektorów, branż czy łańcuchów produkcyjnych generuje szczególne korzyści w regionie, np. sadowniczym czy chowu bydła mlecznego w Polsce.

Specjalizacja produkcji rolnej jest pojęciem dość szerokim, obejmującym problematykę badawczą z zakresu struktury produkcji rolnej i kierunków produkcyjnych rolnictwa, a zwłaszcza kierunków produkcji towarowej, które w literaturze określane są jako kierunki specjalizacji rolnictwa. Kulikowski (2003, s. 98) zdefiniował specjalizację rolnictwa jako proces ciągły polegający na ograniczaniu liczby produktów z jednoczesnym doskonaleniem ich wytwarzania. Gospodarstwa rolne zajmujące się wytwarzaniem wąskiej grupy produktów mogą coraz to bardziej doskonalić (specjalizować) sposób ich wytwarzania, osiągając lepszą jakość wytwarzanych produktów (Kulikowski 2003).

Zjawisko specjalizacji w rolnictwie może być rozpatrywane zarówno od strony kierunków specjalizacji (kierunków produkcji), a więc tego, w czym dane gospodarstwo lub obszar się specjalizuje, jak i od strony stopnia specjalizacji, czyli w jakim stopniu dane gospodarstwo lub rolnictwo jakiegoś obszaru jest wyspecjalizowane (Szyrmer 1975). W rolnictwie pojęcie specjalizacji dotyczy tego, co najlepiej w danym gospodarstwie rolnym produkować i sprzedawać, aby osiągnąć jak największe zyski. W tym rozumieniu celem specjalizacji jest zwiększenie produkcji towarowej, wzrost wydajności pracy, osiąganie lepszej opłacalności produkcji i dochodów z gospodarstwa rolnego (Tłuczak 2018).

\section{Metody badań}

Badania nad specjalizacją produkcyjną rolnictwa w ujęciu regionalnym, określaną także mianem towarowości, prowadzili Szyrmer (1975), Dąbrowski (1977), Kołodziejczak (1995), Kulikowski (2003, 2012, 2013) i Tłuczak (2016, 2018). Specjalizacja regionalna jest często identyfikowana przez porównanie struktury gospodarczej regionu do struktury kraju. Zasadniczym problemem prowadzenia badań nad poziomem specjalizacji rolnictwa jest dobór miernika lub mierników.

Szymer (1975) w badaniach nad rolnictwem Polski zastosował zmodyfikowany wskaźnik specjalizacji autorstwa Kostrowickiego wg wzoru:

$$
W_{i}=\sqrt{\sum_{i=1}^{n} a_{i j}^{i}}
$$

gdzie:

$W_{i}$ - wskaźnik stopnia specjalizacji $i$ jednostki,

$a_{i j}^{i}$ - udział j-tego produktu w produkcji towarowej i-tej jednostki,

$n$ - liczba produktów towarowych i-tej jednostki.

Wskaźnik przyjmuje wartość od 0 do 100 i jest on dobry do badań specjalizacji w skali gospodarstw rolnych, natomiast metoda nie za bardzo sprawdza się w badaniach geograficznych opartych na danych struktury produkcji towarowej rolnictwa w skali regionów (Kulikowski 2003). 
Dąbrowski (1977, s. 65-80) w swoich badaniach stosował wskaźnik względnej specjalizacji regionalnej (WWSR), biorąc pod uwagę poziom produkcji towarowej lub końcowej albo wartość skupu. Wskaźnik względnej specjalizacji regionalnej obliczano wg następującego wzoru:

$$
W W S R_{a j}=\frac{P_{a i}}{P_{x j}} \cdot \frac{U_{a j}}{U_{x j}} \cdot 100
$$

gdzie:

$W W S R_{a j}$ - wskaźnik względnej specjalizacji regionalnej,

$P_{a j} \quad$ - poziom produkcji (końcowej, towarowej) lub skupu produktu $j \mathrm{w}$ badanej jednostce terytorialnej $a$,

$P_{x j} \quad$-średni poziom krajowy produkcji produktu $j$,

$U_{a j} \quad-$ udział produktu j w strukturze produkcji jednostki terytorialnej $a$,

$U_{x j} \quad$-średni krajowy udział produktu $j$ w strukturze produkcji ogólnokrajowej.

Z uwagi na to, że udział konkretnego produktu w strukturze produkcji badanej jednostki odnoszony jest tu do średniego udziału tego produktu w strukturze produkcji krajowej, wskaźnik Dąbrowskiego nadaje się bardziej do poszukiwania rejonów produkcji konkretnych produktów na tle szerszego regionu lub kraju niż do określania stopnia specjalizacji produkcji rolnej (Kulikowski 2003).

Obecnie pomiarów regionalnej specjalizacji produkcji rolnej dokonuje się wykorzystując indeks specjalizacji względnej Krugmana (1993). Indeks Krugmana oblicza się jako sumę różnic bezwzględnych między udziałami sektorowymi produkcji rolnej w określonym regionie w produkcji rolnej ogółem tego regionu, a udziałami produkcji rolnej wg rodzajów ogółem w całkowitej produkcji rolnej (Suchecki 2010):

gdzie:

$$
K_{r} \stackrel{s}{=} \sum\left[u_{r}^{i}-u_{i}\right]
$$

$K_{r}$ - indeks specjalizacji względnej Krugmana,

$u_{r}^{i}$ - udział sektora i produkcji rolnej w regionie $r$,

$u_{i}$ - udział sektora i produkcji rolnej w całkowitej produkcji rolnej.

Indeks specjalizacji Krugmana przyjmuje wartości z przedziału od 0 do 2. Wartość 0 oznacza, że brana pod uwagę struktura gospodarcza regionu jest identyczna jak przeciętna struktura w innych regionach. Im wyższa wartość indeksu, tym większa jest specjalizacja danego regionu.

Spośród wielu miar, jakie przedstawiono do określenia poziomu specjalizacji regionalnej w badaniach wykorzystano iloraz lokalizacji $L Q$. Zasadniczym celem stosowania ilorazu lokalizacji oraz analizy jego wartości jest wskazanie rodzajów kluczowych typów produkcji rolnej w danym województwie. Wskaźnik specjalizacji regionalnej jest to stosunek wartości wskaźnika określonej działalności gospodarczej $S_{i}$ występującej w regionie $i$ do wartości tego wskaźnika $A$ w jednostce przestrzennej wyższego rzędu, czyli kraju.

$$
L Q_{i}=\frac{S_{i}}{A}
$$

$L Q>1$ określa, w których regionach występuje nadreprezentacja danej działalności, a $L Q<1-$ w których względy niedobór. Nadreprezentacja jest interpretowana jako specjali- 
zacja regionalna. Iloraz lokalizacji (LQ) stwarza również możliwość porównań dla różnych momentów czasowych, ponieważ spełnia funkcję podobną do standaryzacji cech (Czyż 2016).

Do badań regionalnej specjalizacji produkcji rolnej wykorzystano iloraz lokalizacji, bazując na udziałach roślinnej i zwierzęcej produkcji towarowej w produkcji towarowej.

$$
W_{s}=\frac{P_{i j}}{P_{i}}
$$

gdzie:

$W_{s}$ - wskaźnik specjalizacji regionalnej,

$P_{i j}-$ udział produkcji towarowej $i$ w regionie $j$,

$P_{i}$ - udział produkcji towarowej $i$ ogółem.

Zastosowana miara określa stosunek udziału typu towarowej produkcji rolnej w gospodarce regionalnej (województwa) do udziału danego typu towarowej produkcji rolnej w gospodarce kraju, którego ten region jest częścią.

Iloraz lokalizacji poza dostarczeniem statycznego obrazu sytuacji do analiz porównawczych pozwala na dokonanie porównań w odniesieniu do dynamiki wskaźnika specjalizacji oraz na wskazanie różnic w dynamice zmian poszczególnych specjalizacji produkcji rolnej. Obliczono tempo zmiany poziomu specjalizacji regionalnej w trakcie badanego okresu wg wzoru:

gdzie:

$$
\Delta W_{s}=\frac{W_{s t+1}-W_{s t}}{W_{s t}}
$$

$W_{s t+1}$ - wartość wskaźnika specjalizacji w ostatnim roku analizowanego okresu,

$W_{s t}$ - wartość wskaźnika specjalizacji w pierwszym roku analizowanego okresu.

W zależności od uzyskanych wartości wskaźnika specjalizacji oraz jego dynamiki badane regiony można pogrupować następująco:

1) $W_{s}>1$ oraz $\Delta W_{s}>0$ - regiony, które uzyskują wysoką wartość wskaźnika specjalizacji oraz występuje korzystna dynamika zmian; rolnicy działający w ramach tej klasy traktowani są jako „koła napędowe” lokalnej gospodarki rolnej;

2) $W_{s}<1$ oraz $\Delta W_{s}>0$ - występuje brak specjalizacji produkcji rolnej, widoczny jest wzrost wskaźnika specjalizacji; rolnicy zaliczeni do tej klasy mogą stać się w przyszłości potencjalnym źródłem dochodów dla lokalnej gospodarki rolnej;

3) $W_{s}>1$ oraz $\Delta W_{s}<0$ - grupuje województwa według typów produkcji rolnej, dla których występuje wysoki wskaźnik specjalizacji, ale ich znaczenie dla regionu maleje;

4) $W_{s}<1$ oraz $\Delta W_{s}<0$ - grupuje województwa według typów produkcji rolnej, które mają najmniejsze znaczenie dla rozwoju gospodarki lokalnej, tj. o niskiej wartości wskaźnika specjalizacji i niekorzystnym kierunku jego zmian (Tłuczak 2017).

\section{Wyniki badań}

Od akcesji Polski do Unii Europejskiej nastąpił dynamiczny wzrost eksportu produktów rolnych z Polski do krajów Europy Zachodniej i napływ środków finansowych w ramach Wspólnej Polityki Rolnej (dopłaty bezpośrednie, wsparcie z tytułu gospodarowania na niekorzystnych warunkach ONW, programy rolnośrodowiskowe), które spowodowały wzrost produkcji towarowej (ryc. 1). 


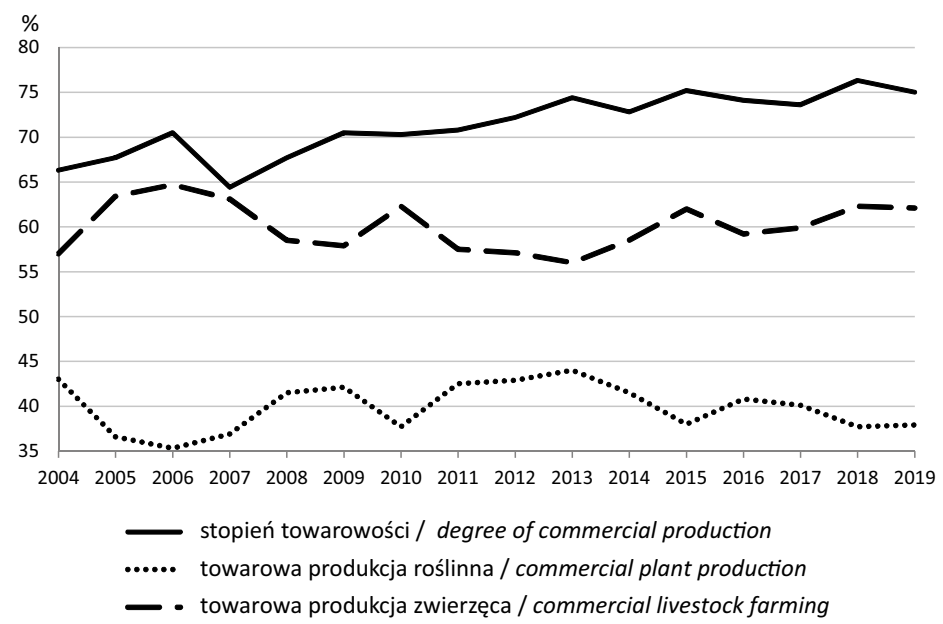

Ryc. 1. Towarowość produkcji rolnej i struktura produkcji towarowej w Polsce w latach 2004- 2019 Źródło: opracowanie własne na podstawie danych GUS.

Commodity of agricultural production and structure of commercial production in Poland in 2004-2019 Source: author's own elaboration based on CSO (GUS) data.

W analizowanym okresie udział produkcji towarowej w produkcji globalnej pomimo tendencji wzrostowej od 66,3\% w 2004 r. do 74,3\% w 2019 r. ulegał nieznacznym wahaniom w latach 2006, 2010, 2015 i 2017. Na wzrost produkcji towarowej miały wpływ znaczące zmiany, jakie zaszły w liczbie i powierzchni gospodarstw rolnych zajmujących się zarówno produkcją roślinną, jak i zwierzęcą. W produkcji roślinnej ubyło gospodarstw produkujących warzywa, ziemniaki, buraki cukrowe i zboża, a przybyło gospodarstw uprawiających rzepak i kukurydzę. W produkcji zwierzęcej pomiędzy analizowanymi latami wystąpiły dość istotne, aczkolwiek zróżnicowane procesy przemian strukturalnych w zależności od gatunku i rodzaju chowu. Duży udział w produkcji towarowej nadal mają gospodarstwa indywidualne, w latach 2010-2015 udział ten przekroczył 88\%, a w 2018 r. nieznacznie zmalał do 87\%. Pomimo zmiennych uwarunkowań w produkcji rolnej wysoki udział produkcji towarowej w produkcji globalnej wskazuje na proces przestawiania się gospodarstw indywidualnych na produkcję przeznaczoną głównie na rynek (Rolnictwo... 2020).

Produkcja roślinna, która jest bardziej związana z warunkami klimatycznymi niż zwierzęca, charakteryzowała się większym zróżnicowaniem i zmieniała się w czasie. W strukturze produkcji towarowej przeważała produkcja zwierzęca nad roślinną. W analizowanym okresie w strukturze towarowej produkcji rolnej udział produkcji roślinnej w 2007 r. zmniejszył się w stosunku do 2004 r. o 6,1 p.p., z powodu spadku udziału produkcji towarowej zbóż, upraw przemysłowych i owoców. W 2007 r. nastąpił spadek stopnia towarowości rolnictwa do 64,4\% spowodowany nieurodzajnym 2006 r. przede wszystkim w zbiorach zbóż i ich wysokimi cenami. W produkcji roślinnej wystąpił wyraźny wzrost na skutek zwiększenia się udziału zbóż (o 3,7 p.p.) oraz ziemniaków (o 1 p.p.), a zmniejszenia się udziału buraków cukrowych (o 0,6 p.p.) i owoców (o 1,8 p.p.). Zmniejszył się udział produkcji zwierzęcej z 58,1\% w 2006 r. do 56,3\% w 2007 r. (Rolnictwo... 2008).

W latach 2008-2019 udział produkcji roślinnej miał tendencję wzrastającą i w 2019 r. w stosunku do 2007 r. wzrósł o 1 p.p. Lata 2015 i 2018 charakteryzowały się spadkiem 
udziału roślinnej produkcji towarowej o 2,4 p.p. w stosunku do poprzednich lat z powodu zmniejszonej towarowej produkcji zbóż, upraw przemysłowych i owoców na skutek suszy. Na poziom udziału towarowej produkcji zwierzęcej w towarowej produkcji ogółem w latach 2008-2019 wpłynął przede wszystkim wyraźny wzrost udziału towarowej produkcji mleka (o 3,6 p.p.; Rolnictwo... 2020).

W badanym okresie brakiem regionalnej specjalizacji produkcji roślinnej charakteryzowały się województwa: podlaskie, warmińsko-mazurskie i wielkopolskie. Jednym z powodów było przeznaczenie produkcji roślinnej, w szczególności zbóż, na pasze dla zwierząt gospodarskich (tab. 1; ryc. 2).

Do regionów charakteryzujących się brakiem specjalizacji, a w których w latach 2007 ¡ 2019 pojawił się średni poziom specjalizacji roślinnej produkcji towarowej, należały łódzkie i śląskie (specjalizacja 2007 r.) oraz podkarpackie z wysokim poziomem specjalizacji (2019 r.). W przypadku województwa mazowieckiego od 2013 r. pojawił się brak specjalizacji roślinnej produkcji towarowej.

W badanym okresie wysoką specjalizacją cechowały się województwa: zachodniopomorskie, dolnośląskie i opolskie oraz świętokrzyskie i lubelskie. W 2019 r. do tej grupy o wysokim poziomie specjalizacji roślinnej dołączyło województwo lubuskie, małopolskie i podkarpackie.

W przypadku województwa pomorskiego w latach 2004 i 2007 odnotowano wysoki poziom specjalizacji, natomiast na skutek suszy w 2013 r. wystąpił brak specjalizacji, a w 2019 r. region ten osiągnął średni poziom specjalizacji produkcji roślinnej. Na podstawie badań PSR 2010 w produkcji pszenicy specjalizowały się województwa: dolnośląskie, lubuskie i zachodniopomorskie, natomiast w produkcji żyta i ziemniaków: małopolskie, podkarpackie i świętokrzyskie (Kacprzak i Kołodziejczak 2014). Rzepak dobrze plonuje na glebach lżejszych, o ile są utrzymane w wysokiej kulturze i zasobne w składniki pokarmowe. Dlatego też specjalizację regionalną w produkcji rzepaku zidentyfikowano w województwach: lubuskim, zachodniopomorskim, dolnośląskim, opolskim, pomorskim i - w 2018 r. - w kujawsko-pomorskim (Tłuczak 2017).

Tabela 1. Specjalizacja regionalna roślinnej produkcji towarowej w Polsce w latach 2004-2019

\begin{tabular}{|l|c|c|c|c|c|}
\hline \multirow{2}{*}{ Województwo } & \multicolumn{2}{|c|}{ Wartości wskaźnika specjalizacji regionalnej } & Tempo zmian poziomu \\
\cline { 2 - 5 } & $\mathbf{2 0 0 4}$ & $\mathbf{2 0 0 7}$ & $\mathbf{2 0 1 3}$ & $\mathbf{2 0 1 9}$ & $\mathbf{s}$ specjalizacji \\
\hline dolnośląskie & 1,50 & 1,81 & 1,68 & 1,84 & 0,226 \\
kujawsko-pomorskie & 1,02 & 1,07 & 1,05 & 1,15 & 0,124 \\
lubelskie & 1,23 & 1,27 & 1,43 & 1,70 & 0,376 \\
lubuskie & 1,02 & 1,15 & 1,20 & 1,20 & 0,178 \\
tódzkie & 0,97 & 1,13 & 0,92 & 0,94 & $-0,034$ \\
małopolskie & 1,09 & 1,12 & 1,10 & 1,38 & 0,263 \\
mazowieckie & 1,13 & 1,08 & 0,99 & 0,86 & $-0,239$ \\
opolskie & 1,34 & 1,46 & 1,35 & 1,43 & 0,068 \\
podkarpackie & 0,73 & 0,77 & 0,96 & 1,27 & 0,736 \\
podlaskie & 0,32 & 0,26 & 0,28 & 0,20 & $-0,362$ \\
pomorskie & 1,23 & 1,37 & 0,99 & 1,02 & $-0,172$ \\
śląskie & 1,00 & 1,01 & 0,98 & 0,83 & $-0,164$ \\
świętokrzyskie & 1,25 & 1,33 & 1,30 & 1,45 & 0,154 \\
warmińsko-mazurskie & 0,65 & 0,68 & 0,78 & 0,65 & 0,008 \\
wielkopolskie & 0,68 & 0,71 & 0,69 & 0,73 & 0,065 \\
zachodniopomorskie & 1,30 & 1,48 & 1,39 & 1,39 & 0,070 \\
\hline
\end{tabular}

Źródło: obliczenia własne na podstawie danych GUS. 

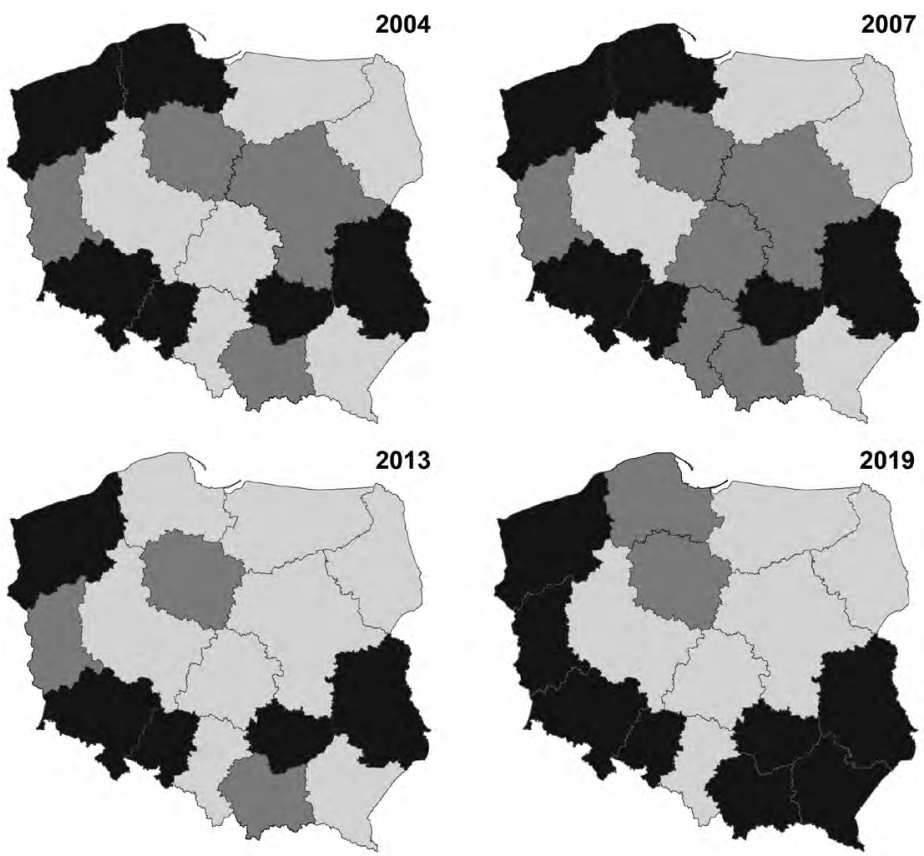

Poziom specjalizacji Level of specialization

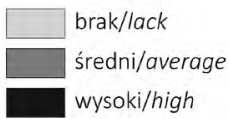

Ryc. 2. Regionalne zróżnicowanie specjalizacji produkcji roślinnej w Polsce w latach 2004, 2007, 2013 i 2019 Źródło: opracowanie własne na podstawie danych GUS.

Regional variation of specialization in crop production in Poland in 2004, 2007, 2013 and 2019

Source: author's own elaboration based on CSO (GUS) data.

Aby zweryfikować postawioną hipotezę badawczą dokonano jednoczesnej analizy wartości wskaźnika specjalizacji oraz jego dynamiki. Na tej podstawie można było wyróżnić województwa, które uzyskują wysoką wartość wskaźnika specjalizacji oraz w których występuje korzystna dynamika zmian. Rolnicy działający w ramach klasy 1 są „kołami napędowymi" lokalnego rolnictwa i przyczyniają się do wzrostu towarowej produkcji roślinnej i zwierzęcej.

Do klasy 1 należały województwa, w których zachodziły pozytywne zmiany w zakresie specjalizacji produkcji roślinnej $\left(W_{s}>1\right.$ i $\left.\Delta W_{s}>0\right)$. Są to tzw. liderzy towarowej produkcji roślinnej (tab. 2). Skupiska tych regionów położone były na południu kraju: dolnośląskie, opolskie, w południowo-wschodniej Polsce: małopolskie, podkarpackie, lubelskie, a w zachodniej części - lubuskie i zachodniopomorskie oraz kujawsko-pomorskie.

Województwa pomorskie i świętokrzyskie specjalizują się w produkcji roślinnej, ale jej znaczenie dla regionów maleje.

Specjalizacja regionalna produkcji zwierzęcej wyglądała inaczej niż produkcji roślinnej. Miały na to wpływ przede wszystkim instrumenty WPR, które nie zapobiegły ograniczeniu pogłowia zwierząt, a w szczególności bydła. Generalnie w produkcji zwierzęcej obserwujemy utrzymywanie się regionalizacji chowu poszczególnych gatunków zwierząt gospo- 
Tabela 2. Klasyfikacja zmian towarowej produkcji roślinnej ze względu na poziom i dynamikę wskaźnika specjalizacji

\begin{tabular}{|l|l|l|}
\hline Klasa & Wartości $\boldsymbol{W}_{s} \mathbf{i} \boldsymbol{\Delta} \boldsymbol{W}_{s}$ & \multicolumn{1}{c|}{ Województwa } \\
\hline 1 & $W_{s}>1$ i $\Delta W_{s}>0$ & $\begin{array}{l}\text { dolnośląskie, kujawsko-pomorskie, lubelskie, lubuskie, małopolskie, opolskie, } \\
\text { podkarpackie, zachodniopomorskie }\end{array}$ \\
2 & $W_{s}<1$ i $\Delta W_{s}>0$ & warmińsko-mazurskie, wielkopolskie \\
3 & $W_{s}>1$ i $\Delta W_{s}<0$ & pomorskie, świętokrzyskie \\
4 & $W_{s}<1$ i $\Delta W_{s}<0$ & łódzkie, mazowieckie, podlaskie, śląskie \\
\hline
\end{tabular}

Źródło: opracowanie własne na podstawie danych GUS.

darskich. Zdaniem Czudec et al. (2017) w produkcji mleka i żywca wołowego dominujące znaczenie mają trzy województwa: mazowieckie, podlaskie i wielkopolskie. W produkcji żywca wieprzowego wiodącą rolę odgrywają od lat cztery województwa: wielkopolskie, kujawsko-pomorskie, mazowieckie i łódzkie, a produkcja owiec jest tradycyjnie skupiona w województwie małopolskim. Różnice w skali i koncentracji produkcji zwierzęcej pogłębiają się pomiędzy poszczególnymi regionami, co wskazuje także na postępujący proces specjalizacji gospodarstw rolnych i tym samym regionalnej specjalizacji rolnictwa.

Brakiem regionalnej specjalizacji produkcji zwierzęcej w badanym okresie charakteryzowały się województwa zachodniopomorskie, lubuskie, dolnośląskie, opolskie, małopolskie oraz świętokrzyskie, lubelskie i kujawsko-pomorskie. W przypadku województwa łódzkiego odnotowano w 2007 r. brak specjalizacji, natomiast w latach 2004, 2013 i 2019 region ten cechował się średnim poziomem specjalizacji produkcji zwierzęcej (tab. 3; ryc. 3).

Podobnie było z województwem mazowieckim, które w latach 2004 i 2007 nie posiadało specjalizacji produkcji zwierzęcej, natomiast od 2013 r. charakteryzowało się średnim poziomem specjalizacji.

W badanym okresie regionalnej specjalizacji produkcji zwierzęcej towarzyszyło powstawanie coraz liczniejszej grupy gospodarstw bezinwentarzowych. W 2010 r. 42\%

Tabela 3. Specjalizacja regionalna zwierzęcej produkcji towarowej w Polsce w latach 2004-2018

\begin{tabular}{|c|c|c|c|c|c|}
\hline \multirow{2}{*}{ Województwo } & \multicolumn{4}{|c|}{ Wartość wskaźnika specjalizacji regionalnej } & \multirow{2}{*}{$\begin{array}{l}\text { Tempo zmian poziomu } \\
\text { specjalizacji }\end{array}$} \\
\hline & 2004 & 2007 & 2013 & 2019 & \\
\hline dolnośląskie & 0,62 & 0,52 & 0,46 & 0,45 & $-0,216$ \\
\hline kujawsko-pomorskie & 0,98 & 0,96 & 0,96 & 0,89 & $-0,076$ \\
\hline lubelskie & 0,82 & 0,84 & 0,66 & 0,64 & $-0,303$ \\
\hline lubuskie & 0,98 & 0,91 & 0,84 & 0,94 & $-0,110$ \\
\hline łódzkie & 1,02 & 0,93 & 1,06 & 1,04 & 0,016 \\
\hline małopolskie & 0,93 & 0,93 & 0,93 & 0,85 & $-0,174$ \\
\hline mazowieckie & 0,90 & 0,95 & 1,01 & 1,09 & 0,204 \\
\hline opolskie & 0,74 & 0,73 & 0,72 & 0,77 & $-0,008$ \\
\hline podkarpackie & 1,20 & 1,13 & 1,03 & 0,91 & $-0,306$ \\
\hline podlaskie & 1,51 & 1,43 & 1,57 & 1,52 & $-0,018$ \\
\hline pomorskie & 0,82 & 0,79 & 1,01 & 1,05 & 0,197 \\
\hline śląskie & 1,00 & 0,99 & 1,01 & 1,08 & 0,100 \\
\hline świętokrzyskie & 0,81 & 0,81 & 0,76 & 0,74 & $-0,100$ \\
\hline warmińsko-mazurskie & 1,27 & 1,19 & 1,17 & 1,29 & 0,043 \\
\hline wielkopolskie & 1,24 & 1,17 & 1,24 & 1,13 & $-0,059$ \\
\hline zachodniopomorskie & 0,77 & 0,72 & 0,69 & 0,76 & $-0,015$ \\
\hline
\end{tabular}

Źródło: obliczenia własne na podstawie danych GUS. 

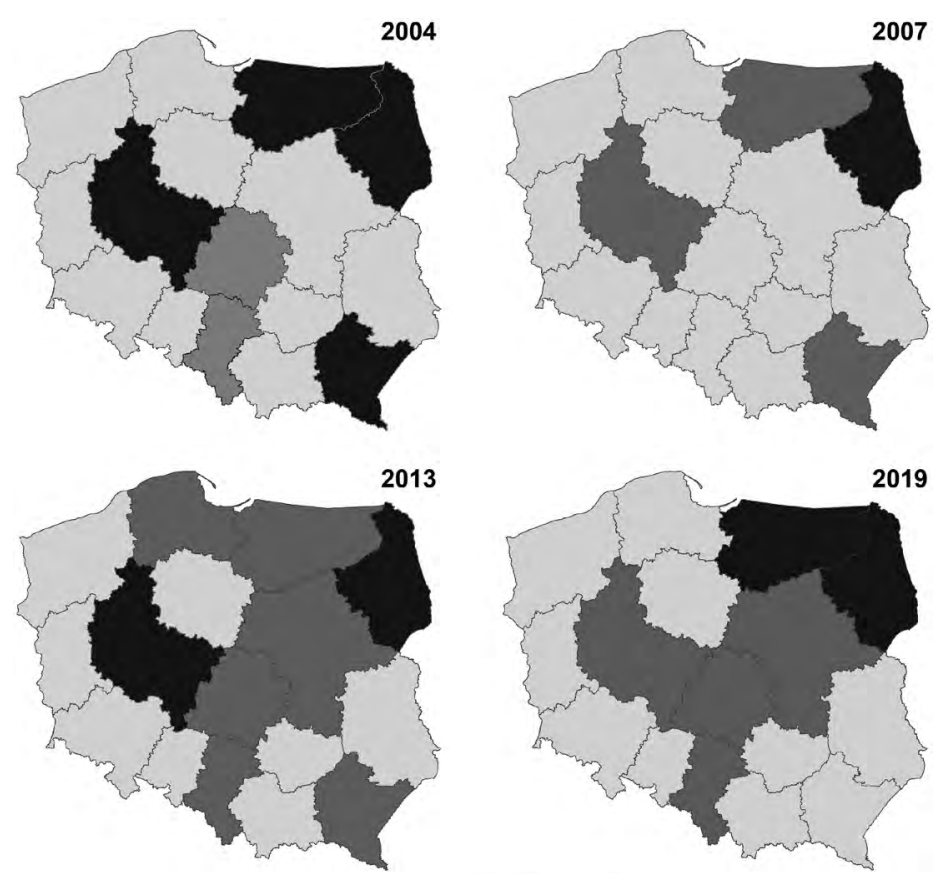

Poziom specjalizacji Level of specialization

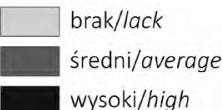

Ryc. 3. Regionalne zróżnicowanie specjalizacji produkcji zwierzęcej w Polsce w latach 2004, 2007, 2013 i 2018 Źródło: opracowanie własne na podstawie danych GUS.

Regional variation of specialization in animal production in Poland in 2004, 2007, 2013 and 2018 Source: author's own elaboration based on CSO (GUS) data.

ogółu gospodarstw rolnych w Polsce nie prowadziło produkcji zwierzęcej (Kuś i Matyka 2013). W późniejszych latach proces ten dalej postępował, tyle że miał różną skalę w poszczególnych województwach. Z chowu zwierząt najczęściej rezygnowały gospodarstwa najdrobniejsze (do 5 ha) produkujące głównie na samozaopatrzenie oraz gospodarstwa największe specjalizujące się w towarowej produkcji roślinnej.

Inną przyczyną było to, że w okresie akcesji Polski do UE odnotowano w województwach o rozdrobnionym i relatywnie ekstensywnym rolnictwie zmniejszenie się liczby gospodarstw rolnych utrzymujących bydło. Nastąpiło wyraźne zmniejszenie odsetka gospodarstw utrzymujących krowy, ograniczenie stada krów mlecznych w związku z większą specjalizacją gospodarstw rolnych i wysokimi wymaganiami jakościowymi dla mleka krowiego, przy jednoczesnym wzroście wydajności mleka od jednej krowy (Kuś i Matyka 2013). Spadek liczby gospodarstw prowadzących chów bydła mlecznego był najszybszy w województwach o rozdrobnionym rolnictwie (Polska południowo-wschodnia) oraz w województwach opolskim i dolnośląskim.

Pomimo tego zjawiska na poziom regionalnej specjalizacji produkcji zwierzęcej wpłynął przede wszystkim wyraźny wzrost udziału towarowej produkcji mleka. Dotyczyło to regionów północno-wschodniej Polski tj. podlaskiego i warmińsko-mazurskiego, które 
również specjalizowały się w produkcji mięsa wołowego, a warmińsko-mazurskie dodatkowo w produkcji drobiu. Województwo wielkopolskie posiadało również wysoki i średni poziom specjalizacji nie tylko w produkcji mleka i mięsa wołowego, ale przede wszystkim wieprzowego (obsada trzody chlewnej na 100 ha użytków rolnych jest ponad dwukrotnie wyższa od średniej krajowej).

W latach 2013-2019 odnotowano trend wskazujący na rezygnację wielu rolników z chowu trzody chlewnej, co było związane z niską opłacalnością chowu tego gatunku zwierząt i ma wpływ na specjalizację produkcji zwierzęcej (Rolnictwo... 2020).

Analiza poziomów specjalizacji produkcji zwierzęcej i korzystnych zmian dynamiki wskaźnika w badanym okresie wykazała, że w województwach łódzkim, mazowieckim, śląskim oraz pomorskim i warmińsko-mazurskim produkcja zwierzęca jest „kołem napędowym" dla lokalnych gospodarek rolnych (tab. 4).

Województwa podlaskie i wielkopolskie specjalizują się w produkcji zwierzęcej, lecz znaczenie tej produkcji dla regionu powoli maleje. W klasie 4 są regiony, w których jest najmniejsze znaczenie produkcji zwierzęcej dla rozwoju gospodarki lokalnej, tj. o niskiej wartości wskaźnika specjalizacji i niekorzystnym kierunku jego zmian.

Tabela 4. Klasyfikacja zmian towarowej produkcji zwierzęcej ze względu na poziom i dynamikę wskaźnika specjalizacji

\begin{tabular}{|l|l|l|}
\hline Klasa & Wartości $\boldsymbol{W}_{s}$ i $\Delta \boldsymbol{W}_{s}$ & \multicolumn{1}{c|}{ Województwa } \\
\hline 1 & $W_{s}>1$ i $\Delta W_{s}>0$ & łódzkie, mazowieckie, pomorskie, śląskie, warmińsko-mazurskie \\
2 & $W_{s}<1$ i $\Delta W_{s}>0$ & - \\
3 & $W_{s}>1$ i $\Delta W_{s}<0$ & podlaskie, wielkopolskie \\
4 & $W_{s}<1$ i $\Delta W_{s}<0$ & $\begin{array}{l}\text { dolnośląskie, kujawsko-pomorskie, lubelskie, lubuskie, małopolskie, opolskie, } \\
\text { podkarpackie, świętokrzyskie, zachodniopomorskie }\end{array}$ \\
\hline
\end{tabular}

Źródło: opracowanie własne na podstawie danych GUS.

\section{Podsumowanie}

Przeprowadzone wielokrotnie badania dotyczące regionalnej specjalizacji produkcji rolnej w oparciu o produkcję towarową za pomocą różnych metod wykazały, że na poziom specjalizacji wpływ mają jakość rolniczej przestrzeni produkcyjnej, warunki pogodowe, poziom kultury rolnej oraz, w okresie akcesji Polski do UE, wysokość środków finansowych WPR. Dynamika zmian towarowej produkcji rolnej wykazała, że w większości przypadków w Polsce występuje specjalizacja regionalna i jest ona zmienna w czasie. Oznacza to, że poziom produkcji towarowej (roślinnej i zwierzęcej) różni się w ramach danego województwa od tych odnotowanych dla całego kraju. Można wskazać na poziom wysokiej specjalizacji produkcji roślinnej w województwach zachodnich oraz południowo-wschodnich Polski. Wynika to z różnej struktury agrarnej rolnictwa, sposobu gospodarowania, a także ze wzrostu liczby gospodarstw bezinwentarzowych na tych obszarach. W przypadku wysokiej specjalizacji produkcji zwierzęcej wiąże się to przede wszystkim z obszarami trwałych użytków zielonych - województwa podlaskie, warmińsko-mazurskie - oraz dużymi gospodarstwami prowadzącymi chów bydła i trzody chlewnej - wielkopolskie (wysoki i średni poziom specjalizacji). 
Badania potwierdziły zależność specjalizacji produkcji rolnej od stopnia towarowości rolnictwa, wysokości środków finansowych WPR i warunków klimatycznych w danym roku (susza). Miały one wpływ na kierunki zmian regionalnej specjalizacji produkcji roślinnej i zwierzęcej. Do klasy województw posiadających specjalizację i korzystne zmiany dynamiki wskaźnika specjalizacji w produkcji roślinnej należały regiony zachodniej i południowo-zachodniej części kraju (zachodniopomorskie, lubuskie, dolnośląskie i opolskie), południowo-wschodniej Polski (małopolskie, lubelskie i podkarpackie) oraz kujawsko-pomorskie, natomiast w przypadku produkcji zwierzęcej - województwa łódzkie, mazowieckie, warmińsko-mazurskie oraz śląskie.

Zdaniem Kulikowskiego $(2013)$ i Tłuczak $(2016,2017)$ rolnictwo ma duży potencjał produkcyjny wynikający z dużych zasobów siły roboczej oraz dużych zasobów ziemi. Pozycja konkurencyjna rolnictwa wynika po części ze stosunkowo niskich kosztów produkcji, postępującej terytorialnej specjalizacji produkcji oraz koncentracji w ważnych sektorach, takich jak mleko, zboża, oraz owoce i warzywa. Badania potwierdziły, że nadal regionalna specjalizacja produkcji rolnej nie odzwierciedla potencjału rolnictwa poszczególnych regionów Polski.

Kulikowski (2013) prognozując przemiany rolnictwa w Polsce w perspektywie 2020 r. stwierdził: „W perspektywie najbliższych kilkunastu lat przewidywany jest też wzrost produktywności ziemi na obszarach już wyspecjalizowanego rolnictwa oraz na terenach o korzystnych warunkach dla produkcji rolnej. Większy wzrost nastąpi w przypadku produktywności pracy i związany będzie z postępującą racjonalizacją zatrudnienia w rolnictwie. Poza przewidywanymi zmianami w poziomie cech produkcyjnych rolnictwa, polegającymi na jego wzroście, w najbliższych latach nie ulegnie większym zmianom ogólny obraz przestrzennego zróżnicowania produktywności i towarowości rolnictwa w Polsce".

W 2020 r. prognoza przemian rolnictwa się sprawdziła. Akcesja Polski do UE przyczyniła się do wzrostu zainteresowania rolników produkcją rolną, wyrażającego się między innymi znacznym ograniczeniem powierzchni gruntów okresowo nieuprawianych i wzrostem eksportu produktów rolnych, co znalazło odzwierciedlenie w poziomie regionalnej specjalizacji produkcji rolnej.

\section{Bibliografia}

Camagni, R., Capello, R., Caragliu, A. (2016). Static vs. Dynamic Agglomeration Economies. Spatial Context and Structural Evolution behind Urban Growth. Regional Science, 95(1), 133-159.

Czudec, A., Kata, R., Miś, T. (2017). Efekty polityki rolnej Unii Europejskiej na poziomie regionalnym. Poznań: Bogucki Wydawnictwo Naukowe.

Czyż, T. (2016). Metoda wskaźnikowa w geografii społeczno-ekonomicznej. Rozwój Regionalny i Polityka Regionalna, 34, 9-16.

Dąbrowski, P. (1977). Przestrzenne zróżnicowanie produkcji towarowej rolnictwa w Polsce (1960-1970). Studia KPZK PAN, 56. Warszawa: Komitet Przestrzennego Zagospodarowania Kraju PAN.

Głębocki, B. red. (2014). Zróżnicowanie przestrzenne rolnictwa. PSR 2010. Warszawa: GUS.

Kacprzak, E., Kołodziejczak, A. (2014). Zmiany w strukturze przestrzennej upraw polowych. W: B. Głębocki (red.), Zróżnicowanie przestrzenne rolnictwa. Powszechny Spis Rolny 2010 (s. 200-253). Warszawa: GUS. 
Kołodziejczak, A. (1995). Regionalna specjalizacja produkcji rolniczej w Polsce. W: Studia z geografii społeczno-ekonomicznej (s. 155-157). Poznań: Wydawnictwo PTPN.

Kopaczewska, K., Churski, P., Ochojski, A., Polko, A. (2016). Specjalizacja regionalna - systematyzacja pojęć i metod pomiaru. Studia KPZK, 170, 8-25.

Krasowicz, S. (2009). Regionalne zróżnicowanie zmian w rolnictwie polskim. Studia i Raporty IUNG$P I B, 15,9-36$.

Krugman, P. (1991). Geography and Trade, Institute of Economic Research Working Papers. Cambridge: the MIT Press.

Kulikowski, R. (2003). Syntetyczne metody badań produktywności i towarowości rolnictwa. Prace Geograficzne, 187. Warszawa: Instytut Geografii i Przestrzennego Zagospodarowania PAN.

Kulikowski, R. (2012). Produktywność i towarowość rolnictwa w Polsce, Barometr Regionalny, 30(4), 17-29.

Kulikowski, R. (2013). Produkcja i towarowość rolnictwa w Polsce. Przemiany i zróżnicowanie przestrzenne po Il wojnie światowe. Prace Geograficzne, 241. Warszawa: Instytut Geografii i Przestrzennego Zagospodarowania PAN.

Kuś, J., Matyka, M. (2013). Zróżnicowanie warunków przyrodniczych i organizacyjnych produkcji rolniczej w Polsce. W: J.S. Zegar (red.), Z badań nad rolnictwem społecznie zrównoważonym (20). Wybrane zagadnienia zrównoważonego rozwoju rolnictwa (s. 47-70). Program Wieloletni 2011-2014, 93. Warszawa: Instytut Ekonomiki Rolnictwa i Gospodarki Żywnościowej-PIB.

Overman, H.G., Gibbons, S., Tucci, A. (2009). The Case for Agglomeration Economies. Report for Manchester Independent Economic Review.

Rolnictwo w 2007 r. (2008). Warszawa: GUS.

Rolnictwo w 2019 r. (2020). Warszawa: GUS.

Suchecki, B. red. (2010). Ekonometria przestrzenna. Metody i modele analizy danych przestrzennych. Warszawa: C.H. Beck.

Szyrmer, J.H. (1975). Stopień specjalizacji rolnictwa. Próba zastosowania nowej metody mierzenia, Przeglad Geograficzny, 47(1), 117-135.

Tłuczak, A. (2016). Regionalna specjalizacja produkcji rolnej w Polsce, Studia Obszarów Wiejskich, 42, 209-216.

Tłuczak, A. (2017). Specjalizacja regionalna a potencjał rolnictwa w Polsce. Roczniki Naukowe SERiA, $17(5), 289-296$.

Tłuczak, A. (2018). Specjalizacja i konkurencyjność krajów UE w zakresie produkcji zbóż. Problemy Rolnictwa Światowego, 38(3), 323-331.

\section{Summary}

Agricultural production is subject to continuous economic and structural changes. Since the 1990s economic and organizational factors have exerted greater influence on agricultural production than environmental conditions. An important determinant affecting farming production was Poland's accession to the EU, where agriculture was covered by Common Agricultural Policy. Proportion of plant products does not go directly to the market; it is processed on farms into animal products. At the same time, however, what has been developing for years are unfavorable relations between crop and animal products. The reasons for this state of affairs are complex. One of the ways to improve the results of agricultural production is specialization. This is quite a broad concept, embracing 
the research issue concerning agricultural production structure and directions of agricultural production, especially regarding commercial production which are defined in literature as directions of agricultural specialization (Kulikowski 2003). The aim of the study is to present changes in the regional specialization of crop and livestock production taking place in Poland in the years 2004-2019. An attempt was made to answer the question in which agricultural production does a given region specialize and to what extent? The following research hypothesis was adopted: changes in the specialization of agricultural production in the regions are influenced by farmers benefiting from direct payments and other forms of financial aid under the Common Agricultural Policy. For the research on the regional specialization of agricultural production, the location quotient based on the share of crop and livestock commodity production in commodity production was used. The location quotient, apart from providing a static picture of the situation for comparative analyzes, allows for comparisons with regard to the dynamics of the specialization index, and to indicate differences in the dynamics of changes in individual agricultural production specializations. In the investigated period, crop production which is more dependent on climate conditions than animal breeding was much more diversified (changed over time). Western voivodships achieved a high level of specialization in plant production. It resulted from the agrarian structure of these regions, where large farms dominated. The lack of specialization in plant production was typical of the following voivodships: Podlaskie, Warmińsko-mazurskie and Wielkopolskie. With regard to animal production, the situation was different. The share of commercial animal production in the general commercial output was primarily affected by an apparent increase in the share of commercial milk production. This concerned north-eastern voivodships: Podlaskie and Warmińsko-mazurskie, which specialized in beef production as well. Wielkopolskie Voivodship also reached a high level of specialization not only in beef but mainly in pork production.

Keywords: specialization in agricultural production, commercial production, location quotient. 